\section{Pekkasen komitean ehdotukset}

\section{Tuottava osallistuminen uudistu-} vassa työelämässä. Osallistumisjärjestelmäkomitean I osamietintö: yksityinen sektori. Komiteamietintö 1987:40. Helsinki 1988. $104 \mathrm{~s}$.

Valtioneuvosto asetti v. 1986 komitean selvittämään uusien yhteistoimintamuotojen mahdollisuuksia taloudellisen demokratian ja kilpailukykyisen tuotantotoiminnan edistämiseksi. Komitean puheenjohtajaksi kutsuttiin toimitusjohtaja Matti Pekkanen. Päätoimisena sihteerinä toimi valt. tri Heikki Oksanen.

Komitean näkemyksen mukaan sekä ulkoiset että sisäiset tekiiät aiheuttavat ensi vuosikymmenellä mittavan tarpeen kehittää Suomen talouselämän rakenteita ja toimintatapoja. Tämä edellyttää yritysten sisäisen toiminnan kehittämistä lisäämällä monipuolisesti johdon ja henkilökunnan yhteistoimintaa.

Komitean ehdotuksissa käsitellään henkilöstöantoja, henkilöstölle palkan lisäksi maksettavia voittopalkkioita sekä henkilöstörahastoja, jotka loisivat mahdollisuuden järjestää henkilöstön yhteinen osaomistus työnantajayrityksessä. Rahastot perustuisivat voittopalkkiojärjestelmään.

Koulutus on komitean ehdotuksisssa keskeisellä sijalla. Seuraavassa tiivistelmä koulutusta koskevista ehdotuksista lukijakunnan arvioitaviksi.

\section{Täydennyskoulutus ja uudelleensijoittaminen}

Työntekijöiden täydennys- ja uudelleenkoulutuksen tarve on tulevalla vuosikynnenellä niin merkittävä, että sekä aikuiskoulutusjärjestelmä että tämän koulutuksen taloudelliset edellytykset tulee uudistaa perusteellisesti. Tämä vaatii valtiovallan, yritysten ja palkansaajien laajaa yhteistyötä.

Keski-ikäisen ja sitä vanhemman väestön osuus kasvaa 1990luvulla merkittävästi. Tämän takia täydennyskoulutusta on lisättävä rohkeasti ja samalla sen painopistettä on siirrettävä nykyistä van- hempiin ikäluokkiin.

Työvoiman siirtyminen eläkkeelle ennen normaalia eläkeikää on viime aikoina lisääntynyt tuntuvasti. Komitea katsoo, että vastaisuudessa on luotava olosuhteet, joissa työntekijät pysyvät nykyistä pitempään työelämässä. Tämän takia yritysten henkilöstölle on järjestettävä taloudelliset ja muut edellytykset osallistua täydennyskoulutukseen ja siirtyä riittävän turvallisesti työtehtävästä toiseen.

Komitea katsoo, että yritysten tulee vastata työvoimansa kehittämisestä nykyistä selkeämmin. Tämä on niille välttämätöntä, jotta niillä olisi tulevaisuudessa palveluksessaan ammattitaitoista työvoimaa. Valtiovalta voi kannustaa yrityksia tehostamaan työvoimansa koulutusta ja uudelleensijoittamista vaikuttamalla koulutuksen ja työvoimansa vähentämisen yrityksille aiheuttamiin kustannuksiin. Samalla viranomaisten osallistumista rakennemuutosten edistämiseen ja niihin liittyvien häiriöiden lieventämiseen tulee tehostaa.

\section{Omaehtoinen \\ aikuiskoulutus}

Aikuisten omaehtoisen ammatillisen täydennys- ja uudelleenkoulutuksen kehittämiseksi komitea ehdottaa valtion opintotukikeskuksen toiminnan tuntuvaa kehittämistä aikuisopiskelijoiden tarpeita vastaavasti.

Nuorisoasteen koulutuksesta vapautuvaa kapasiteettia voidaan suunnata aikuisten ammatilliseen koulutukseen. Informaatiotekniikan kehittyminen mahdollistaa nykyistä monipuolisemman ja taloudellisemman opiskelun. Koulutusjärjestelmän on pystyttävä reagoimaan nykyistä joustavammin koulutuksen tarpeeseen.

Komitea suosittaa, että 1990-luvulla ainakin osa mahdollisesta työajan lyhentämisestä suunnataan aikuisopiskeluun. Tämän toteuttamiseksi tulee harkita sellaisia työmarkkinasopimuksia, joiden perusteella kehitetään palkallisen opintovapaan muotoja.

\section{Yritysten \\ henkilöstökoulutus}

Yritysten henkilöstökoulutusta on edistetty $\mathrm{mm}$. työmarkkinajär- jestöjen suosituksin. Komitea katsoo, että henkilöstökoulutuksessa päästään parhaisiin tuloksiin järjestämällä se yrityksen johdon ja henkilöstön yhteistyönä. Komitea ehdottaakin selvitettäväksi, millaisia menettelytapoja yrityksissä voitaisiin soveltaa henkilöstökoulutuksesta sopimiseksi.

Komitea pitää tärkeänä, että oppilaitosten ja yritysten välistä yhteistyötä tiivistetaan mm. oppilaitosten organisoimaa työpaikkakoulutusta lisäämällä. Lisäksi opettajille ja muille henkilöille tulee järjestää mahdollisuuksia siirtyä määräaikaisesti opetustyöstä ja hallinnosta yrityksiin ja päinvastoin.

\section{Työvoiman \\ uudelleensijoittaminen}

Tuotannon rakenteen muuttuessa eivät ennaltaehkäisevät toimenpiteet riitä kokonaan poistamaan paikallisia työllisyyskriisejä. Tämän takia komitea katsoo, että sekä keskushallinnon että lääni- ja paikallishallinnon viranomaisten toimintaa kriisien hoitamiseksi tulee tehostaa ja perustaa tätä varten pysyvät elimet.

Komitea katsoo, että erorahoja ja muita työpaikkansa menettäneille maksettavia korvauksia on ainakin osittain muutettava koulutusrahoiksi, joiden avulla työntekijät voivat hankkia itselleen valmiudet siirtyä urusiin tehtäviin.

Komitean mielestä yritysten on kannettava nykyistä enemmän vastuuta työntekijöittensä kouluttamisesta ja pitämisestä työelämässä nykyistä pitempään. Tämän vuoksi komitea pitää tärkeänä, että selvitetään yrityskohtaisen kustannusvastuun osittaista aikaansaamista erorahoihin ja muihin irtisanomiskorvauksiin sekä kustannusvastuun selvää lisäämistä siirrettäessä työntekijöitä ennenaikaisesti eläkkeelle. Samalla tulee selvittää muihin mahdollisiin yrityksille asetettaviin työvoiman kouluttamista ja uudelleensijoittamista koskeviin velvoitteisiin liittyviä hyötyjä ja haittoja. 